\title{
Validity of the Hungarian Version of the Subjective Happiness Scale (SHS-HU)
}

\author{
ATTILA SZABO ${ }^{1,2}$ \\ ${ }^{1}$ Institute of Psychology, ELTE Eötvös Loránd University, Budapest, Hungary \\ ${ }^{2}$ Institute of Health Promotion and Sport Sciences, ELTE Eötvös Loránd University, \\ Budapest, Hungary
}

(Received: 19 January 2019, accepted: 28 March 2019)

\begin{abstract}
Validated in several languages, the Subjective Happiness Scale (SHS) is a popular and reliable instrument used in the assessment of perceived happiness. The aims of two current studies were to determine the psychometric properties of the Hungarian version in volunteer adults $(N=252)$ and non-volunteer university students $(N=142)$. Exploratory factor analysis of the data gathered from volunteers confirmed the unidimensional structure of the Hungarian SHS (SHS-HU). One component explained 53.69\% of the variance. The internal reliability in this sample was .80 . Confirmatory factor analyses on the non-volunteer university students' data yielded excellent model fit (SRMR $=.0208$; $\mathrm{NFI}=$. 990; GFI = .995; RMSEA < .001; CFI = 1.00) and acceptable internal reliability (.75). The one-week test-retest reliability of the SHS-HU was 0.83. In both studies, the SHS-HU revealed positive correlations with life satisfaction and optimism, while it was inversely related to pessimism $(p<.001)$. The more optimistic individuals scored higher on SHS-HU in both studies $(p<.001)$ which confirmed the scale's divergent validity. Further, when controlling for life satisfaction, optimism and pessimism, there were no gender differences in the SHS-HU scores. These results lend support for the adequate psychometric properties of SHS-HU. Therefore, preliminary evidence suggests that the SHS-HU is appropriate for the assessment of perceived happiness in the Hungarian population.
\end{abstract}

Keywords: affect, life satisfaction, well-being, optimism, pessimism

\section{Introduction}

\subsection{Happiness}

The meaning of happiness has preoccupied philosophers, scholars and writers since the beginning of the modern age (Haller \& Hadler, 2006). A major goal, and for many people the meaning, of life is to experience happiness (Buss, 2000; Sato et al., 2015). Happiness, in Diener's (2000) view,

\footnotetext{
* Correspondence: Prof. Attila Szabo, Institute of Health Promotion and Sport Sciences, ELTE Eötvös Loránd University, 1117 Budapest, Hungary, Bogdánfy Ödön u. 10. E-mail: szabo.attila@ ppk.elte.hu
} 
is the mirror of one's subjective wellbeing and vice versa. For example, the later could be used as an index of happiness (Diener, 2000, p. 34.). The subjective nature of happiness is determined by cognitive, emotional, and genetic interactions which show an association with the gray matter's volume in the right precuneus area of the brain as determined with structural magnetic resonance imaging (Sato et al., 2015). Subjective happiness is the core in the research of wellbeing, positive psychology, and life-satisfaction (Diener, 2000; Lopez et al., 2018). Its importance in the field of Psychology, in general, is undisputed.

\subsection{Measuring subjective happiness}

Several instruments were developed for the assessment of the subjective happiness. A one-item scale was used in early research (Shin \& Johnson, 1978) and later it was claimed that this method is both valid and reliable (Abdel-Khalek, 2006). The Happiness Measures is a two-item scale that is based on the subjective rating of one's happiness and the percent of time felt as happy, neutral, or unhappy (Fordyce, 1988; Wessman \& Ricks, 1966). This very brief measure possesses excellent psychometric properties (Fordyce, 1988). The Affectometer 2 (Kammann \& Flett, 1983), which is the successor of 96-item Affectometer 1, is a 40-item self-rating scale based on 10 mnemonic qualities of happiness such as cheerfulness, self-esteem, optimism, etc. While this tool is rather lengthy, it was employed in several studies. The 24-item Memorial University of Newfoundland Scale of Happiness (MUNSH; Kozma \& Stones, 1980) was originally devised for measuring happiness in elderly, but it was rarely used in the literature. The 20-item Oxford Happiness Inventory (Argyle et al., 1989) and its successor Oxford Happiness Questionnaire (Hill and Argyle, 2002) were both criticized for length, redundancy, conceptual confound and lack of a sound theoretical rationale (Kashdan, 2004). The Orientation to Happiness Scale (Peterson et al., 2005) is an 18-item instrument designed to assess an individual's orientations to happiness by the pursuit of pleasure, engagement and meaning. While translated into a few languages, the scale's validity was questioned based on empirical findings (Henderson et al., 2013). Developed twenty years ago, probably one of the most popular tools in the assessment of happiness is the Subjective Happiness Scale (SHS; Lyubomirsky \& Lepper, 1999). Its wide use stems from its brevity (4 items) and internationally reported validity and reliability (translated into more than ten languages). Additionally, it is easy to administer and to score. 


\subsection{The Subjective Happiness Scale}

This tool has been translated into several languages: Arabic (Moghnie \& Kazarian, 2012), Chinese (Nan et al., 2014), German and Tagalog (Swami et al., 2008), Greek (Karakasidou et al., 2016; Lyrakos et al., 2013), Italian (Iani et al., 2013), Japanese (Shimai et al., 2004), French (Kotsou \& Leys, 2017), Malay (Swami, 2008), Portuguese (Damásio et al., 2014; Spagnoli et al., 2012), Russian (Lyubomirsky \& Lepper, 1999), Serbian (Jovanović, 2013), Spanish (Extremera \& Fernández-Berrocal, 2013; Quezada et al., 2016; VeraVillarroel, 2011), and Turkish (Dogan \& Totan, 2013). It is a unidimensional instrument which comprises four items rated on a 7-point Likert scale. The mean values obtained with the SHS range between 4.02 and 5.62 across several international samples (Figure 1). The internal reliability of the scale ranges from (Cronbach's $\alpha$ ) .65 to .94 across several international versions (Table 1).

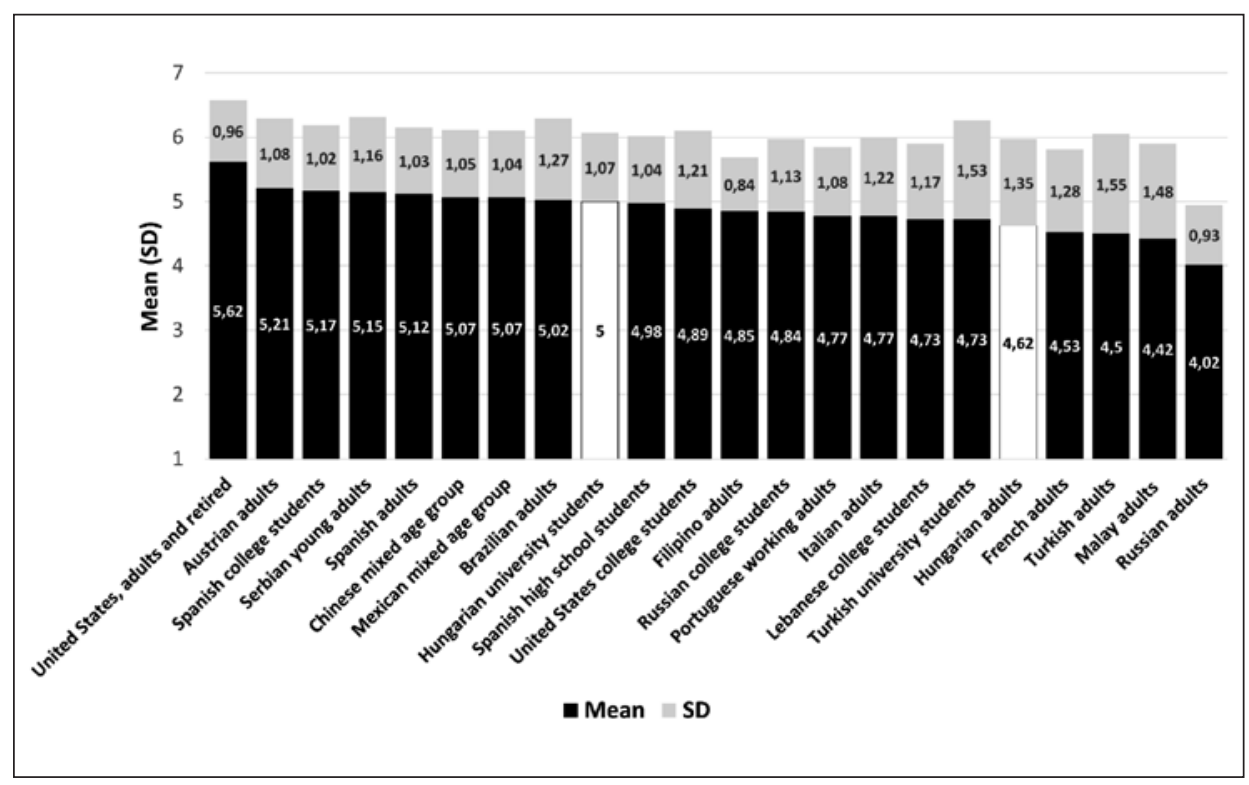

Figure 1. Mean subjective happiness scores, with the standard deviations indicated above the bars, reported for several international samples highlighting (in white) the position of the two samples studied in the current work. 
Table 1. Internal reliabilities reported for the Subjective Happiness Scale (SHS) in various international samples

(when three decimals were reported, they were rounded to two)

\begin{tabular}{|c|c|c|}
\hline National Sample & Reliability $(N)$ & Author(s)/ year \\
\hline $\begin{array}{l}\text { Arabic (Lebanon, college } \\
\text { students) }\end{array}$ & $.74(273)$ & Moghnie \& Kazarian (2011) \\
\hline Brazilian-Portuguese (Brasil) & $.84(600)$ & Damásio et al. (2014) \\
\hline Chinese (Hong Kong) & $.82(2635)$ & Nan et al. (2014) \\
\hline Chinese (Malaysia) & $.91(290)$ & Swami (2008) \\
\hline English (USA) & $.86(198)$ & Lyubomirsky \& Lepper (1999) \\
\hline English (USA) & $.91(83)$ & Strizzi et al. (2016) \\
\hline English (USA, college students) & $.84-.94(2124)$ & Lyubomirsky \& Lepper (1999) \\
\hline English (USA, town females) & $.85(92)$ & Lyubomirsky \& Lepper (1999) \\
\hline English (USA, high school & $.81(36)$ & Lyubomirsky \& Lepper (1999) \\
\hline English (USA, retired) & $.86(622)$ & Lyubomirsky \& Lepper (1999) \\
\hline French (International) & $.83(1554)$ & Kotsou \& Leys (2017) \\
\hline German (Austria) & $.82(960)$ & Swami et al. (2009) \\
\hline Greek (Greece) & $.76(6948)$ & Karakasidou et al. (2016) \\
\hline Greek (Greece) & $.76(856)$ & Lyrakos et al. (2013) \\
\hline Hungarian (Hungary) & $.80(252)$ & Current study \\
\hline $\begin{array}{l}\text { Hungarian (Hungary, college } \\
\text { students) }\end{array}$ & $.75(142)$ & Current study \\
\hline Italian (Italy) & $.79(993)$ & Iani et al. (2013) \\
\hline Japanese (Japan, men) & $.80(158)$ & Shimai et al. (2004) \\
\hline Japanese (Japan, women) & $.84(206)$ & Shimai et al. (2004) \\
\hline Malay (Malaysia) & $.94(227)$ & Swami (2008) \\
\hline Portuguese (Portugal) & $.77(1017)$ & Spagnoli et al. (2012) \\
\hline Russian (Russia) & $.79(63)$ & Lyubomirsky \& Lepper (1999) \\
\hline Russian (Russia, college students) & $.80(67)$ & Lyubomirsky \& Lepper (1999) \\
\hline Serbian (Serbia, college students) & $.83(605)$ & Jovanović (2013) \\
\hline Spanish (Chile) & $.73-.87(1079)$ & Vera-Villarroel et al. (2011) \\
\hline Spanish (Mexico) & $.77(849)$ & Quezada et al. (2016) \\
\hline
\end{tabular}




\begin{tabular}{|l|l|l|}
\hline \multicolumn{1}{|c|}{ National Sample } & \multicolumn{1}{|c|}{ Reliability $(\mathrm{N})$} & \multicolumn{1}{|c|}{ Author(s) / year } \\
\hline Spanish (Spain) & $.83(261)$ & $\begin{array}{l}\text { Extremera \& Fernández-Berrocal } \\
(2013)\end{array}$ \\
\hline Spanish (Spain) & $.77(157)$ & Strizzi et al. (2016) \\
\hline Spanish (Spain, college students) & $.83(466)$ & $\begin{array}{l}\text { Extremera \& Fernández-Berrocal } \\
(2013)\end{array}$ \\
\hline $\begin{array}{l}\text { Spanish (Spain, high school } \\
\text { students) }\end{array}$ & $.79(428)$ & $\begin{array}{l}\text { Extremera \& Fernández-Berrocal } \\
(2013)\end{array}$ \\
\hline Tagalog (Philippines) & $.78(182)$ & Swami et al. (2008) \\
\hline Turkish (Turkey) & $.70(222)$ & Dogan \& Totan (2013) \\
\hline Turkish (Turkey, college students) & $.65(348)$ & Dogan \& Totan (2013) \\
\hline
\end{tabular}

The objective of the current work was to assess the validity and reliability of the SHS in Hungarian. While the Orientation to Happiness Scale (Peterson et al., 2005) was not long ago validated in Hungarian (Szondy \& Martos, 2014), this tool's validity was challenged (Henderson et al., 2013). Further it is longer and measures three aspects of happiness-orientations rather than subjectively interpreted happiness per se. The Hungarian scholars need a reliable and valid tool for measuring happiness and the SHS, as based on several cross-cultural validations over the past 15 years, appears to be a promising tool that might fulfill this need. A translated, but not validated, version of the SHS has been already used in a published Hungarian research (Kun \& Szabó, 2017) suggesting the urgent need for a validated version of the scale.

\section{Method}

\subsection{Study 1}

\subsubsection{Participants}

Participants for Study 1 were recruited via a call for participation in a popular national magazine available both online and offline. In total 312 individuals agreed to participate within a period of two weeks in November 2018, however only 252 of them completed the study. Their mean $(M)$ age was 42.95 years $(S D=14.56$ years, ranging from 18 to 82 years). Measures of height and weight were: $M=168.99 \mathrm{~cm}(S D=8.10 \mathrm{~cm}$, range $148-195 \mathrm{~cm})$, and $M=71.84 \mathrm{~kg}(S D=16.29 \mathrm{~kg}$, range: $43-130 \mathrm{~kg})$, respectively. The majority were women $(203 / 252)$. 


\subsubsection{Materials}

Three demographic questions were posed. These asked participants to provide their gender, age, height and weight. Three brief scales were used to assess the subjective happiness, optimism and pessimism, and satisfaction with life.

The Subjective Happiness Scale (Lyubomirsky \& Lepper, 1999) was translated forth and back by two independent academics and a PhD student. The final agreed Hungarian version (SHS-HU) was then further examined and approved by the author who is fluent in English. The scale comprises four items. The first asks about perceived happiness in general. The second item asks about subjective happiness relative to peers, while the third in relation to those who no matter what happens to them enjoy life. Finally, the fourth item inquires about perceived happiness relative to people who do not seem to be happy and even though they are not depressed, they do not appear as happy as they could be (this item is inversely rated). Each item is rated on a 7-point Likert scale. The four ratings are added to yield a total score for perceived happiness. A higher score indicates greater happiness.

The revised Life Orientation Test (LOT-R) was used to measure optimism and pessimism (Scheier et al., 1994). The scale consists of 10 items. Three items assess optimism, while another three items assess pessimism; the remaining four are filler items. It was shown that the optimism and pessimism items represent independent constructs (Herzberg et al., 2006). The psychometric properties of LOT-R are adequate (Herzberg et al., 2006). Its internal reliability (Cronbach's $a$ ) is .71 for optimism and .68 for pessimism (Herzberg et al., 2006). In the studies reported here the psychometrically validated Hungarian LOT-HU was used (Bérdi \& Köteles, 2010). Its internal reliability was .71 for optimism and .72 for pessimism. High scores indicate high optimism or high pessimism, respectively.

The Satisfaction with Life Scale (SWLS; Diener et al., 1985) was adopted to assess general life satisfaction. The SWLS has five items which are rated on a 7-point Likert scale ranging from strongly disagree to strongly agree. The internal reliability of the SWLS was reported to range between .79 and .89; its test-retest reliability, examined in several periods from one month to four years, ranged between .50 and .84 (Pavot \& Diener, 2008). In the two here reported studies the psychometrically validated Hungarian version of the SWLS-HU was used (Martos et al., 2014). The internal reliability of this scale in the studied samples was .87. Higher scores indicate greater satisfaction with life. 


\subsubsection{Procedure}

Volunteer participants completed the study anonymously on the Qualtrics online research platform (Qualtrics, 2017) having a unique Uniform Resource Locator. Prospective respondents had to be aged 18 years or over and consent to participation by clicking the 'I agree' button following the general information about the study. Only fully completed responses were used in data analyses. The online-collected data were downloaded in a Statistical Package for Social Sciences (SPPS v. 25; IBM Corp. Released 2017) data file and analysed with the same software.

\subsubsection{Compliance with Ethical Standards}

Study 1 was fully anonymous. Ethical permission for the study was obtained from the Research Ethics Board of the Faculty of Education and Psychology at ELTE Eötvös Loránd University in Budapest. All participants had to confirm their voluntary consent to taking part in the study by selecting the 'yes' button on the information and consent page prior to gaining access to the questionnaires on the Qualtrics research platform. They were free to deny consent by interrupting the completion of the questionnaires at any time. About 1/5 (19.23\%) lived with this opportunity.

\subsection{Study 2}

\subsubsection{Participants}

This study was performed as part of the curriculum in an undergraduate course in the area of sport and leisure sciences in the Institute of Health Promotion and Sport Sciences at ELTE Eötvös Loránd University. In contrast to Study 1, this method of participant selection was employed to diminish the bias associated with voluntary participation (Rosenthal, 1965). The sample comprised 142 participants, 88 men and 54 women. Participants' mean $(M)$ age was 19.65 (SD $=1.40$ years). Measures of height and weight were: $M=176.69 \mathrm{~cm}(S D=89.66 \mathrm{~cm}$, range $155-206 \mathrm{~cm})$, and $M=68.80 \mathrm{~kg}$ $(S D=12.54$, range $43-115 \mathrm{~kg})$, respectively. The study was anonymous. Apart from age, gender, height and weight, the participants did not provide any other information. A random sub-sample of 60 participants received a code by an independent assistant that was used to identify themselves for completing the SHS-HU for a second time one-week later for collecting the data needed for the assessment of the test-retest reliability of the SHS-HU. Of the potential 60 participants only 50 were present one week later. 


\subsubsection{Materials}

The materials used in this study were fully identical to those employed in Study 1 . The only difference was that the responses were collected on paper and not online.

\subsubsection{Procedure}

Participants were presented with the demographic questions and the three questionnaires on a one-sided paper distributed by an independent research assistant. The study took place during a scheduled undergraduate class. Interaction and talking was not permitted during the completion of the questionnaires. Participants were instructed that there are no right or wrong answers and that their first hunch is better than thinking too much about their answers. When all participants finished completing the questionnaires, the research assistant collected them and handed over to the principal investigator. Three weeks later the aims, hypotheses, results and the implications of the study were discussed, as part of teaching material, with the students in the course. This research was an integral part of the curriculum in the course.

\subsubsection{Compliance with Ethical Standards}

Although the research was embedded into the course curriculum to demonstrate data collection, recording and basic statistics, ethical permission for the study was obtained from the Research Ethics Board of the Faculty of Education and Psychology at ELTE Eötvös Loránd University. While participants were required to participate, they were free to deny the completion of the questionnaires for any reason, in which case they had to remain in the class as observers to comply with the course-requirements. None of the participants refused to complete the paper and pencil questionnaires.

\section{Results}

\subsection{Study 1}

\subsubsection{Descriptive statistics}

The $M$ of the SHS-HU in Study 1 was $4.62(S D=1.65)$ fitting in with the values reported in several other samples, but towards the lower end (Figure 1). Its median $(M d n)$ value was 4.75 . 


\subsubsection{Exploratory factor analysis}

To examine whether the SHS-HU yields a unidimensional structure, as reported earlier for several translated versions of the scale, an exploratory factor analysis (EFA) was used. The Bartlett's test of sphericity was statistically significant $(\chi 2(6)=407.48, p<.001)$. The Kaiser-Meyer-Olkin (KMO) measure of sampling adequacy was .710, which exceeded the suggested cut-off value for factor analysis (Kaiser, 1974; Yong \& Pearce, 2013). The four items intercorrelated statistically significantly with each other $(p<.001)$ and all correlation coefficients were above .30 (Dabchick \& Fidell, 2007).

The principal axis factoring yielded a single factor solution with an eigenvalue larger than $1.0(=2.54)$ that explained $53.69 \%$ of the variance. ${ }^{1}$ Further, the unidimensional nature of the SHS-HU was confirmed by the scree-plot as well (Cattell 1966; see Figure 2). All four items loaded on the single factor, with adequate factor loadings (i.e., > .4; item $1=.896$; item $2=$ .823 ; item $3=674$, and item $4=.461)$. The internal reliability of the SHS-HU in Study 1 was (Cronbach's a) .80, which fits well within the range (.65 to $.94)$ of the reliabilities reported in several international samples (Table 1).

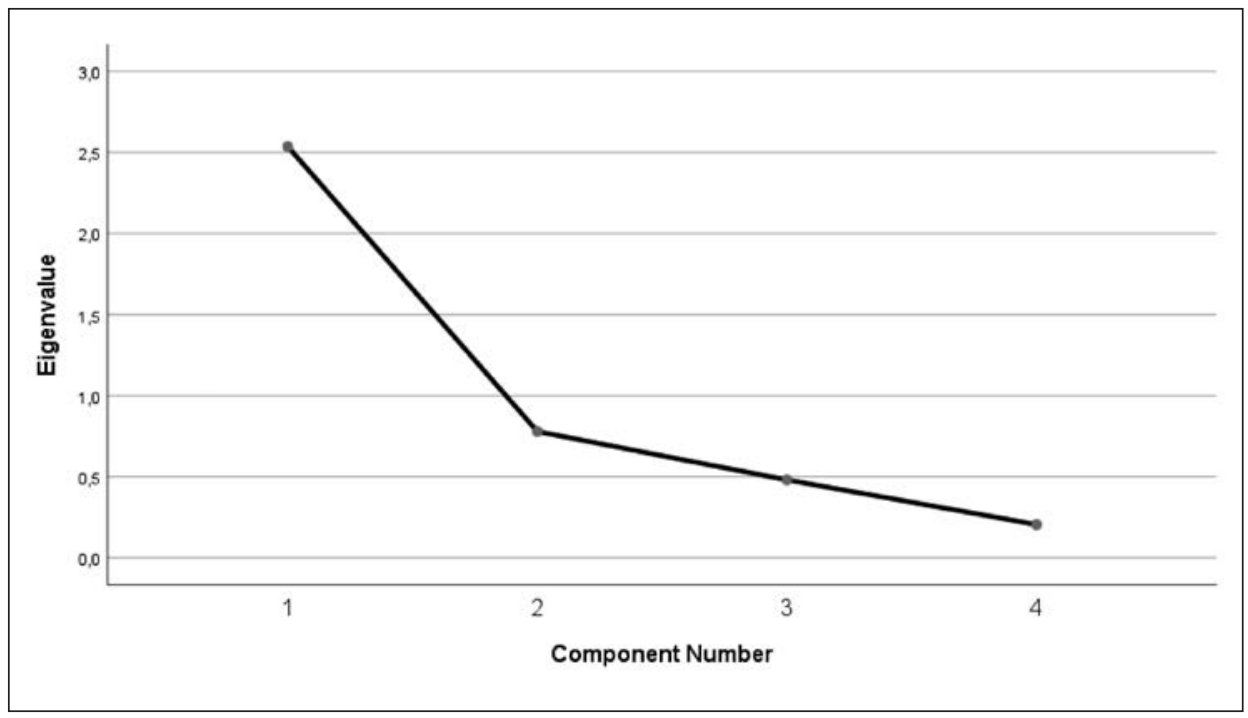

Figure 2. Scree-plot illustrating the unidimensional structure of the Hungarian Subjective Happiness Scale (SHS-HU)

1 Some studies used principal component analysis (PCA) instead of principal axis factoring (PAF). With the former method the variance explained by the single emerging component would be $62.35 \%$ in the current work. 


\subsubsection{Criterion validity}

The SHS-HU correlated positively and statistically significantly with both life satisfaction $(r=.71, p<.001)$ and optimism $(r=.55, p<.001)$. Further, the scale correlated negatively with pessimism $(r=-.53, p<.001)$. These results suggest that the SHS-HU has good criterion validity.

\subsubsection{Construct validity}

Construct validity of the SHS-HU was determined using a cross-sectional method (Terry et al., 2004). First, a median-split was performed on the optimism scores of the respondents. While dichotomization is often criticized in the literature, the method is adequate (Iacobucci et al., 2015) and serves well this purpose. Scores falling right on the median value were excluded from the dichotomization. An analysis of covariance (ANCOVA), using age and gender as covariates, revealed that low- and high-optimists differed statistically significantly in SHS-HU scores $(F(1,204)=57.00, p<$ $.001)$. The former group scored lower $(M=3.91, S D=1.32)$ than the more optimist group $(M=5.24, S D=1.15)$ and the effect size of the difference was large (Cohen's $d=-1.07$; Cohen, 1992). While age was not a significant covariate, gender was $(F(1,204)=3.86, p=.051)$. These results suggest that the scale has good construct validity.

\subsubsection{Gender differences}

Since gender was found to be a significant covariate when testing the construct validity of the SHS-HU, although no gender differences were reported in previous validation studies of the SHS, an ANCOVA was performed to investigate the differences in SHS-HU scores between men and women. Since SHS-HU correlated with both SWLS-HU and the LOTHU scores, satisfaction with life, optimism, and pessimism were used as covariates. The ANCOVA revealed that while all the three covariates were statistically significant $(p \leq .05)$, the mean SHS-HU scores did not differ $(p>$ $.05)$ between men $(M=4.16, S D=1.50)$ and women $(M=4.73, S D=1.29)$. 


\subsection{Study 2}

\subsubsection{Descriptive statistics}

The $M$ of the SHS-HU in Study 2 was $5.00(S D=1.07)$. The median $(M d n)$ value was greater than in Study $1(\mathrm{Mdn}=5)$ and, as based on the MannWhitney $U$-test, it was statistically significantly different $(U=-2.55, p=$ .011). Therefore, the non-volunteer university students scored higher on subjective happiness than the volunteers in Study 1, occupying a higher position within the range of the internationally reported mean scores (refer to Figure 1).

\subsubsection{Confirmatory factor analysis}

The data obtained from this sample was subjected to a confirmatory factor analysis (CFA) to examine whether they conform to the original model (Lyubomirsky and Lepper, 1999). The emerging results yielded excellent fit indices $(\chi 2(2)=6.28, p=.470 ; \mathrm{CMIN} / \mathrm{DF}=.756$; SRMR $=.0208 ; \mathrm{CFI}=1.00$; GFI $=.995 ; \mathrm{NFI}=.990$, and RMSEA $=<001($ CI90: .000 -.154$)$, PCLOSE $=$ .582). Consequently, the CFA yielded good model fit (Figure 3) and considering it together with the results of the EFA in Study 1, the findings suggest that the SHS-HU shows adequate construct validity. The internal reliability of the SHS-HU in Study 2 was $a=.75$, which again fits well within the range (.65 to .94) of the reliabilities reported for various international samples (refer to Table 1).

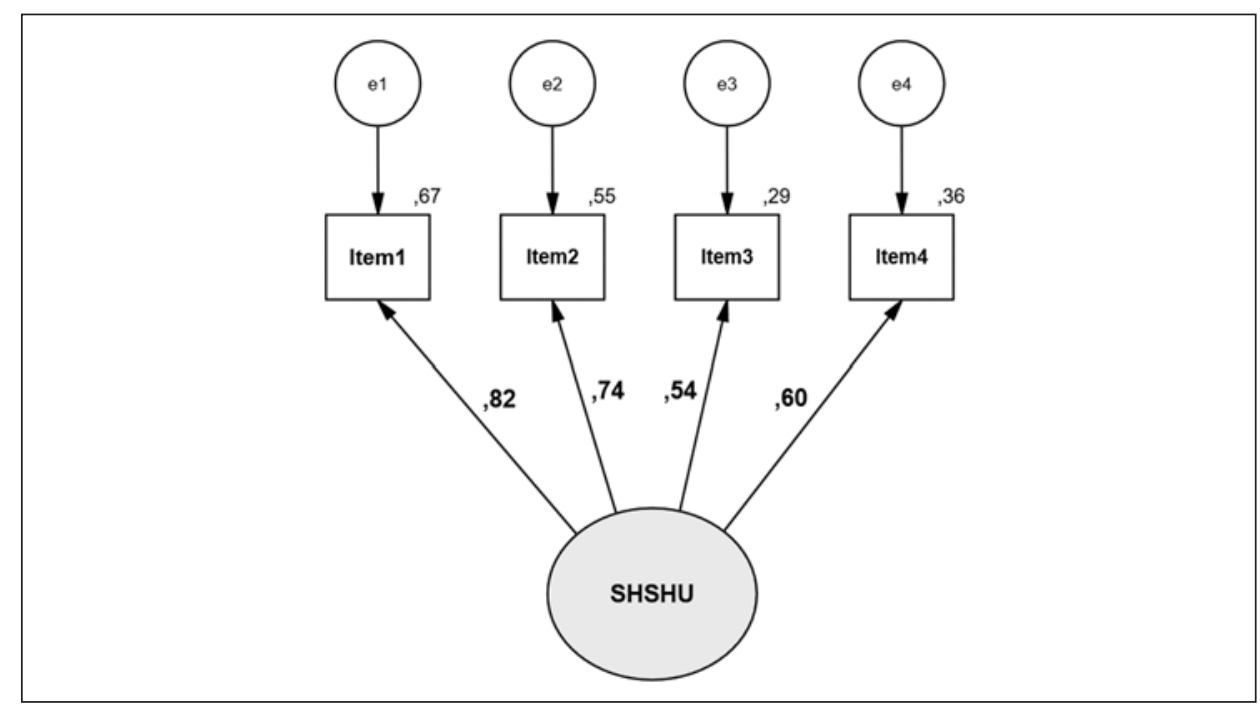

Figure 3. Confirmatory factor analysis model with standardized estimates for the non-volunteer university student sample. 


\subsubsection{Criterion validity}

Similarly to Study 1, the SHS-HU correlated positively and statistically significantly with both life satisfaction $(r=.49, p<.001)$ and optimism $(r=.58, p<.001)$, while being negatively correlated with pessimism $(r=$ $-.46, p<.001)$. These results lend further support for the criterion validity of the scale.

\subsubsection{Construct validity}

Like in Study 1, to examine the construct validity of the SHS-HU, a mediansplit was performed on the optimism scores of the respondents. Scores falling on the median value were excluded from the dichotomization. An ANCOVA, using age and gender as covariates, replicated the key results in Study 1 by showing that low- and high-optimist students differed statistically significantly from each other in their SHS-HU scores $(F(1,117)=$ $31.65, p<.001)$. As expected, low-optimists also scored lower $(M=4.52, S D$ $=1.06)$ on the SHS-HU than high-optimists $(M=5.59, S D=0.84)$. The effect size of the difference was large (Cohen's $d=-1.12$; Cohen 1992). Neither of the two covariates were statistically significant in this analysis. Replicating the findings of the Study 1, these results confirm that the SHS-HU has good construct validity.

\subsubsection{Test-retest reliability}

Although satisfaction with life and happiness are relatively stable over time, it was revealed that there is also a noteworthy degree of instability in these measures that could be ascribed to various contextual circumstances (Lucas \& Donnellan, 2007). Therefore, a one-week intertest interval in examining the test-retest validity of the SHS-HU was considered to be adequate. The correlation based on responses obtained from 50 participants was $r=.83$ between SHS-HU data obtained one week apart. This value is $>.70$ (George \& Mallery, 2003), therefore the SHS-HU has good test-retest reliability.

\section{Discussion}

The results of Study 1 demonstrated that the Hungarian version of Lyubomirsky and Lepper's (1999) SHS is a reliable and valid measure of subjective happiness among a group of volunteer adult Hungarians. The unidimensional nature of the SHS-HU was confirmed as revealed through 
the one factor solution emerging from the EFA. This factor accounted for $53.69 \%$ of the variance, which is a value falling within the range reported for validations in other languages ranging from 45.2\% (Moghnie \& Kazarian, 2012) to $83 \%$ (Swami, 2008). However, these two studies at the two ends of the spectrum used principal components analysis (PCA). Indeed, in the current inquiry the PCA would have yielded a one factor solution accounting for $62.35 \%$ of the total variance. However, when validating an instrument the EFA identifies the factors underlying the dataset based on between-items correlations (Field, 2009) and their highest proportion of variance shared by the component variables. In contrast to PCA, EFA does not assume that all variance in the dataset is shared (Field, 2009), which is rarely the case anyway. Consequently, it is suggested that EFA is more reliable in scale validation than PCA (Costello \& Osborne, 2005). Most of the studies validating the SHS in other languages used EFA (Damásio et al., 2014; Dogan \& Totan, 2013; Jovanović, 2013; Karakasidou et al., 2016; Kotsou \& Leys, 2017; Lyrakos et al., 2013; Nan et al., 2014; Quezada et al., 2016; Shimai et al., 2004; Swami et al., 2008).

Matching the findings of other validation studies (Lyubomirsky \& Lepper, 1999; Kotsou \& Leys, 2017; Mattei \& Schaefer, 2004; Spagnoli et al., 2012; Swami et al., 2009) the results of both Study 1 and Study 2 confirmed the positive relationship between SHS-HU and SWLS-HU in establishing the scale's criterion validity. The association between the two variables was stronger in the volunteer adult sample (.71) in contrast to the non-volunteer university student sample (.49). Nevertheless, both values were statistically significant and fall within the range reported by others in the literature (.35.72; Kotsou \& Leys, 2017; Lyubomirsky \& Lepper, 1999; Mattei \& Schaefer, 2004; Spagnoli et al., 2012; Swami et al., 2009).

Criterion validity was also supported via the positive correlation of the SHS-HU with optimism and negative correlation with pessimism, a relationship that was long ago established (Dember \& Brooks, 1989). Previous studies used the results of the Life Orientation Test (LOT) as a unidimensional tool for assessing dispositional optimism (Dogan \& Totan, 2013; Jovanović, 2013; Karakasidou et al., 2016; Lyubomirsky \& Lepper, 1999) and demonstrated statistically significant correlation between the SHS and optimism (range $r=.11$ to .60). In the present study the LOT-HU was used as a two-dimensional instrument assessing both optimism and pessimism because it was shown that these items reflect independent constructs (Herzberg et al., 2006).

The correlation coefficients of these constructs, yielding opposite relationships with the SHS-HU, ranged from .49 to .55 for optimism and from -.58 to -.53 for pessimism. While the later cannot be compared with 
the results of other validation studies, the values obtained for optimism fall within the range reported in other studies (Dogan \& Totan, 2013; Jovanović, 2013; Karakasidou et al., 2016; Lyubomirsky \& Lepper, 1999) and support further the criterion validity of the SHS-HU.

In their developmental work of the SHS, Lyubomirsky and Lepper (1999) revealed that people who perceived themselves as happy were also optimistic. Their finding provided rationale for testing the construct validity of the scale with the cross-sectional method employed by Terry et al. (2004) by creating high- and low- optimist groups. The opposite correlations of the SHS-HU with optimism and pessimism also supported the use of the method. In both studies reported here people exhibiting greater optimism than the median value scored higher on the SHS-HU than those scoring below the median value of optimism scores. The effect sizes were large and beside supporting the construct validity of the scale, in agreement with Lyubomirsky and Lepper (1999), the results confirm that optimistic individuals feel happier than the less optimistic people.

The results of the CFA in Study 2 confirmed that the SHS-HU conformed to the original model (Lyubomirsky \& Lepper, 1999). The fit indices were similar or better than those reported in other studies carrying out a CFA during the validation of the SHS (Dogan \& Totan, 2013; Iani et al., 2013; Kotsou \& Leys, 2017; Spagnoli et al., 2012). Some studies (i.e., Iani et al., 2013; Spagnoli et al., 2012) only performed a CFA during the validation of the SHS. However, it was advised that both EFA and CFA need to be reported. It was suggested to begin with an EFA to determine the underlying factor structure of the questionnaire, which should be followed by a CFA on data from another sample to assess and verify the EFA-based initial theory about the measure's factor-structure and psychometric properties (Costello \& Osborne, 2005). Like in the validation studies reported by Damásio et al. (2014) and Quezada et al. (2016), in the current work this recommendation was strictly followed.

The test-retest reliability of the scale was good. The one-week intertest period may be too conservative in some opinions, but it was revealed that there is a certain degree of instability in measures of happiness that may be due to contextual circumstances (Lucas \& Donnellan, 2007). Therefore, the one-week interval may be considered to be appropriate. The value obtained in the current work (.83) does not only support the test-retest reliability of the SHS-HU, but also fits well within the range of values (.55-.95) reported in a few studies for other language versions of SHS (Lyubomirsky \& Lepper, 1999; Nan et al., 2014; Swami, 2008).

The internal consistencies obtained in the two studies (.80 and .75) are acceptable for the SHS-HU. These values fall within the range of internal consistencies reported in a variety of international samples (refer to Table 1). 
They are also comparable with the only value reported for a sample of 295 Hungarians (.81) in one recent study that employed a non-validated version of the SHS-HU but determined its internal consistency (Kun \& Szabó, 2017).

The SHS-HU differentiated between the adult volunteer and young adult non-volunteer university student samples. The younger participants appeared to be happier than the older ones as revealed through the statistically significant difference between the two samples (refer to Figure 1). This finding is consistent with another report in the literature suggesting that older people score lower on the SHS, than younger people (Iani et al., 2013). However, in the current work the non-voluntary and voluntary nature of the samples may also play a role, thus any age-related interpretation would be speculative, especially because age was not a significant covariate in the ANCOVAs testing the SHS-HU score-differences between optimism groups.

The differences in the SHS-HU scores were due to some other than agecharacteristics of the two samples. Employing a non-volunteer sample eliminates, at least in part, the concern of bias through self-selection and provides more reliable results. The recruitment of non-volunteers is difficult, if not impossible, in the general population. In this work the embedding of the research within a university course curriculum in Study 2 provided a feasible solution for getting around the issue of volunteerism faced in Study 1. However, the findings emerging from the non-volunteer participants, although complementing and supporting the findings with the volunteers in Study 1, cannot be generalized to other groups. Indeed, Bond and Lang (2018) produced robust evidence that the results of happiness research are biased by beliefs about the ubiquitous nature of happiness in the researched (target) society. The bulk of the results rely on the assumption that all people, in general, experience happiness in an identical fashion. This dilemma was also raised by Frawley (2015) who reviewed the critiques of happiness research and pointed out several issues, with key emphasis on cultural and individual differences and the scientific approach, in general, which are too reductionist and, therefore, miss the heterogeneity in subjective interpretations of happiness. For example, there are national tendencies - promoted via social learning - in positive thinking, which translate into culturally distinct interpretations of happiness (Ehrenreich, 2009). Similarly, within the same society, respondents to a call for study on happiness and university students may have different interpretations that surfaced in the current work too in that university students seemed to be happier than the volunteering adults (see Figure 1). Consequently, the personal meaning of happiness, at both cultural and individual level, should be homogenized, or brought under a sort of common denominator, in research aimed at measuring happiness. 


\section{Limitations and strengths}

The study is not without limitation. Some readers will correctly spot the relatively small sample sizes in the two studies, especially Study 2, which albeit acceptable in preliminary investigations may be a concern. However, the number of items (only 4) in the SHS is few and, therefore, the 10 to 1 person-to-item ratio, which is a rule of thumb, was satisfied (CabreraNguyen, 2010). Further, promising results with a relatively small sample size could be expected to yield even more robust results with larger samples. Another concern is perhaps the gender imbalance in the samples with more women in Study 1 and more men in Study 2. While no gender differences were noted in the current study, which was the case in the other validation studies too, examining a larger sample in which there is a balance between men and women would be desirable. The issue of volunteerism or self-selection encountered in Study 1 was only partially addressed in Study 2 , since the sample in the second study was relatively unique. Despite this limitation, the studying of a non-volunteer sample is a strength of the current work vis-a-vis past SHS validation studies. The following of the guidelines in reporting the scale development and validation results (Cabrera-Nguyen, 2010) may also be considered a strength of this work. The rarely determined and reported test-retest reliability index is also a strength that adds further insight into the reliability of the scale.

\section{Conclusion}

Two studies using different methodologies (online data collection with volunteers and paper and pencil data acquisition with non-volunteers) confirm that the Hungarian version of the Subjective Happiness Scale (Appendix) is a valid and reliable measure of the subjective happiness in Hungarian people. The conclusion is based on good EFA and model fitting CFA, acceptable internal reliability, criterion- and construct validity in both studies, and test-retest reliability demonstrated in Study 2. All the current results agree with the findings reported in other validation studies, in different languages, of the Subjective Happiness Scale.

\section{Acknowledgment}

The "Mindennapi Pszichológia" magazine and its editor Dr. Zsuzsa Pápay Herbert are thanked for their help in recruiting participants for Study 1. Nóra Seregi is thanked for her help in data collection in Study 2. 


\section{Conflict of Interests Statement}

The author has no conflict of interest to declare.

\section{Financial disclosure}

No funding was received for this research.

\section{References}

Abdel-Khalek, A.M. (2006). Measuring happiness with a single-item scale. Social Behavior and Personality: An International Journal, 34(2), 139-150.

Argyle, M., Martin, M., \& Crossland, J. (1989). Happiness as a function of personality and social encounters. In J.P. Forgas, \& J.M. Innes (Eds.), Recent advances in social psychology: an international perspective (189-203). North-Holland: Elsevier

Bérdi, M., \& Köteles, F. (2010). The measurement of optimism: the psychometric properties of the Hungarian version of the Revised Life Orientation Test (LOT-R). Magyar Pszichológiai Szemle, 65(2), 273-294.

Bond, T., \& Lang, K. (2018). The Sad Truth About Happiness Scales: Empirical Results. Working Paper 24853. National Bureau of Economic Research. Doi: doi:10.3386/w24853. Retrieved March 27, 2019, from: https://www.nber.org/papers/w24853.pdf

Buss, D.M. (2000). The evolution of happiness. American Psychologist, 55(1), 15-23.

Cabrera-Nguyen, P. (2010). Author guidelines for reporting scale development and validation results in the journal of the society for social work and research. Journal of the Society for Social Work and Research, 1(2), 99-103.

Cattell, R.B. (1966). The scree test for the number of factors. Multivariate Behavioral Research, 1, 245-276.

Cohen, J. (1992). A power primer. Psychological Bulletin, 112(1), 155-159.

Costello, A.B., \& Osborne, J.W. (2005). Best practices in exploratory factor analysis: Four recommendations for getting the most from your analysis. Practical Assessment, Research \& Evaluation, 10(7), 1-9.

Damásio, B.F., Zanon, C., \& Koller, S.H. (2014). Validation and psychometric properties of the Brazilian version of the Subjective Happiness Scale. Universitas Psychologica, 13(1), 17-24.

Dember, W.N., \& Brooks, J. (1989). A new instrument for measuring optimism and pessimism: Test-retest reliability and relations with happiness and religious commitment. Bulletin of the Psychonomic Society, 27(4), 365-366.

Diener, E. (2000). Subjective well-being: The science of happiness and a proposal for a national index. American Psychologist, 55(1), 34-43.

Diener, E., Emmons, R.A., Larsen, R.J., \& Griffin, S. (1985). The Satisfaction with Life Scale. Journal of Personality Assessment, 49, 71-75.

Dogan, T., \& Totan, T. (2013). Psychometric properties of Turkish version of the Subjective Happiness Scale. The Journal of Happiness and Well-Being, 1(1), 21-28.

Ehrenreich, B. (2009). Bright-sided: How the Relentless Promotion of Positive Thinking Has Undermined America. New York, NY: Metropolitan Books 
Extremera, N., \& Fernández-Berrocal, P. (2013). The Subjective Happiness Scale: Translation and preliminary psychometric evaluation of a Spanish version. Social Indicators Research, 119(1), 473-481.

Field, A. (2009). Discovering Statistics using SPSS. London: Sage

Fordyce, M.W. (1988). A review of research on the happiness measures: A sixty second index of happiness and mental health. Social Indicators Research 20, 355-381.

Frawley, A. (2015). Happiness research: A review of critiques. Sociology Compass, 9(1), 62-77.

George, D., \& Mallery, P. (2003). SPSS for Windows step by step: A simple guide and reference. 11.0 update (4th ed.). Boston: Allyn \& Bacon

Haller, M., \& Hadler, M. (2006). How social relations and structures can produce happiness and unhappiness: An international comparative analysis. Social Indicators Research, 75(2), 169-216.

Henderson, L. W., Knight, T., \& Richardson, B. (2013). The hedonic and eudaimonic validity of the Orientations to Happiness Scale. Social Indicators Research, 115(3), 1087-1099.

Herzberg, P.Y., Glaesmer, H., \& Hoyer, J. (2006). Separating optimism and pessimism: A robust psychometric analysis of the Revised Life Orientation Test (LOT-R). Psychological Assessment, 18(4), 433-438.

Hills, P., \& Argyle, M. (2002). The Oxford Happiness Questionnaire: a compact scale for the measurement of psychological well-being. Personality and Individual Differences, 33(7), 1073-1082.

Iacobucci, D., Posavac, S.S., Kardes, F.R., Schneider, M.J., \& Popovich, D.L. (2015). Toward a more nuanced understanding of the statistical properties of a median split. Journal of Consumer Psychology, 25(4), 652-665.

Iani, L., Lauriola, M., Layous, K., \& Sirigatti, S. (2013). Happiness in Italy: Translation, factorial structure and norming of the Subjective Happiness Scale in a large community sample. Social Indicators Research, 118(3), 953-967.

IBM Corp. Released (2017). IBM SPSS Statistics for Windows, Version 25.0. Armonk, NY: IBM Corp.

Jovanović, V. (2013). Psychometric evaluation of a Serbian version of the Subjective Happiness Scale. Social Indicators Research, 119(2), 1095-1104.

Kaiser, H. (1974). An index of factorial simplicity. Psychometrika, 39, 31-36.

Kammann, R., \& Flett, R. (1983). Affectometer 2: A scale to measure current level of general happiness. Australian Journal of Psychology, 35(2), 259-265.

Karakasidou, E., Pezirkianidis, C., Stalikas, A., \& Galanakis, M. (2016). Standardization of the Subjective Happiness Scale (SHS) in a Greek Sample. Psychology, 7(14), 1753-1765.

Kashdan, T.B. (2004). The assessment of subjective well-being (issues raised by the Oxford Happiness Questionnaire). Personality and Individual Differences, 36(5), 1225-1232.

Kotsou, I., \& Leys, C. (2017). “Echelle de bonheur subjectif (SHS): Propriétés psychométriques de la version française de l'échelle (SHS-F) et ses relations avec le bien-être psychologique, l'affect et la dépression" ["Subjective Happiness Scale (SHS): Psychometric properties of the French version of the scale (SHS-F) and its relationship to psychological wellbeing, affect and depression"]. Canadian Journal of Behavioural Science / Revue canadienne des sciences du comportement, 49(1), 1-6.

Kozma, A., \& Stones, M.J. (1980). The measurement of happiness: Development of the Memorial University of Newfoundland Scale of Happiness (MUNSH). Journal of Gerontology, 35(6), 906-912.

Kun, Á., \& Szabó, A. (2017). Boldogság tényezők a pedagógusok munkájában. Magyar Pszichológiai Szemle, 72(3), 281-310. 
Lopez, S.J., Pedrotti, J.T., \& Snyder, C.R. (2018). Positive psychology: The scientific and practical explorations of human strengths. London: Sage Publications

Lucas, R.E., \& Donnellan, M.B. (2007). How stable is happiness? Using the STARTS model to estimate the stability of life satisfaction. Journal of Research in Personality, 41(5), 10911098.

Lyrakos, G.N., Dragioti, H., Batistaki, C., \& Spinaris, V. (2013). Paper 1460 - Translation and validation study of the subjective happiness scale (shs) in greek general population, diabetes mellitus and patients with emotional disorders. European Psychiatry, 28(S1). Doi:10.1016/s0924-9338(13)76488-5. Retrieved March 27, 2019, from: https:/ /www. europsy-journal.com/article/S0924-9338(13)76488-5/pdf

Lyubomirsky, S., \& Lepper, H.S. (1999). A measure of subjective happiness: Preliminary reliability and construct validation. Social Indicators Research, 46(2), 137-155.

Martos, T., Sallay, V., Désfalvi, J., Szabó, T., \& Ittzés, A. (2014). Psychometric characteristics of the Hungarian version of the Satisfaction with Life Scale (SWLS-H). Mentálhigiéné és Pszichoszomatika, 15(3), 289-303.

Marx, R.G., Menezes, A., Horovitz, L., Jones, E.C., \& Warren, R.F. (2003). A comparison of two time intervals for test-retest reliability of health status instruments. Journal of Clinical Epidemiology, 56(8), 730-735.

Mattei, D., \& Schaefer, C.E. (2004). An investigation of validity of the Subjective Happiness Scale. Psychological Reports, 94(1), 288-290.

Moghnie, L., \& Kazarian, S.S. (2012). Subjective happiness of Lebanese college youth in Lebanon: Factorial structure and invariance of the Arabic Subjective Happiness Scale. Social Indicators Research, 109(2), 203-210.

Nan, H., Ni, M.Y., Lee, P.H., Tam, W.W.S., Lam, T.H., Leung, G.M., et al. (2014). Psychometric evaluation of the Chinese version of the Subjective Happiness Scale: Evidence from the Hong Kong FAMILY Cohort. International Journal of Behavioral Medicine, 21(4), 646-652.

Peterson, C., Park, N., \& Seligman, M.E. (2005). Orientations to happiness and life satisfaction: The full life versus the empty life. Journal of Happiness Studies, 6(1), 25-41.

Pavot, W., \& Diener, E. (2008). The Satisfaction with Life Scale and the emerging construct of life satisfaction. Journal of Positive Psychology, 3, 137-152.

Qualtrics (2017). Survey research suite: Research coreTM. Provo, Utah, USA. Retrieved October 14, 2018, from: http:/ / www.qualtrics.com

Quezada, L., Landero, R., \& González, M.T. (2016). A validity and reliability study of the Subjective Happiness Scale in Mexico. Journal of Happiness $\mathcal{E}$ Well-Being, 4(1), 90-100.

Rosenthal, R. (1965). The volunteer subject. Human Relations, 18(4), 389-406.

Sato, W., Kochiyama, T., Uono, S., Kubota, Y., Sawada, R., Yoshimura, S., et al. (2015). The structural neural substrate of subjective happiness. Scientific Reports, 5: 16891. Doi: 10.1038/ srep16891

Scheier, M.F., Carver, C.S., \& Bridges, M.W. (1994). Distinguishing optimism from neuroticism (and trait anxiety, self-mastery, and self-esteem): A reevaluation of the Life Orientation Test. Journal of Personality and Social Psychology, 67(6), 1063-1078.

Shimai, S., Otake, K., Utsuki, N., Ikemi, A., \& Lyubomirsky, S. (2004). Development of a Japanese version of the Subjective Happiness Scale (SHS), and examination of its validity and reliability. [Nihon koshu eisei zasshi] Japanese Journal of Public Health, 51(10), 845-853.

Shin, D.C., \& Johnson, D.M. (1978). Avowed happiness as an overall assessment of the quality of life. Social Indicators Research, 5(1-4), 475-492.

Spagnoli, P., Caetano, A., \& Silva, A. (2012). Psychometric properties of a Portuguese version of the Subjective Happiness Scale. Social Indicators Research, 105(1), 137-143. 
Strizzi, J., Fernández-Agis, I., Parrón-Carreño, T., \& Alarcón-Rodríguez, R. (2016). Enacted sexual stigma, stigma consciousness, and Subjective Happiness Scale adaptation: a twocountry study. Journal of Interpersonal Violence, 31(2), 316-338.

Swami, V. (2008). Translation and validation of the Malay Subjective Happiness Scale. Social Indicators Research, 88(2), 347-353.

Swami, V., Stieger, S., Voracek, M., Dressler, S.G., Eisma, L., \& Furnham, A. (2009). Psychometric evaluation of the Tagalog and German Subjective Happiness Scales and a cross-cultural comparison. Social Indicators Research, 93(2), 393-406.

Szondy, M., \& Martos, T. (2014). The three faces of happiness: Psychometric properties of the Hungarian version of the Orientations to Happiness Scale. Mentálhigiéné és Pszichoszomatika, 15(3), 229-243.

Tabachnick, B.G., \& Fidell, L.S. (2007). Using multivariate statistics (5th ed.). Boston, MA: Allyn and Bacon

Terry, A., Szabo, A., \& Griffiths, M. (2004). The exercise addiction inventory: a new brief screening tool. Addiction Research and Theory, 12(5), 489-499.

Wessman, A.E. \& Ricks, D.F. (1966). Mood and Personality. New York: Holt, Rinehart and Winston

Vera-Villarroel, P., Celis-Atenas, K., \& Córdova-Rubio, N. (2011). Evaluation of happiness: Psychometric analysis of the subjective happiness scale in Chilean population. Terapia Psicologica, 29(1), 127-133.

Yong, A. G., \& Pearce, S. (2013). A Beginner's Guide to Factor Analysis: Focusing on Exploratory Factor Analysis. Tutorials in Quantitative Methods for Psychology, 9(2), 79-94. 


\title{
APPENDIX
}

\section{The Hungarian Subjective Happiness Scale (Szubjektív Boldogság Skála; SHS-HU)}

\begin{abstract}
1. Általában, azt gondolom magamról, hogy:
Nem vagyok nagyon boldog 1 ....2...............5....6....7 Nagyon boldog vagyok

2. Társaimhoz / barátaimhoz viszonyítva:
\end{abstract}

Kevésbé vagyok boldog $\quad 1 \ldots . .2 \ldots . .3 \ldots . . .4 \ldots . .5 \ldots . .6 \ldots . .7 \quad$ Boldogabb vagyok

3. Vannak, akik általában nagyon boldogok; élvezik az életet, függetlenül attól, hogy mi történik velük. Milyen mértékben jellemző ez önre?

\section{Egyáltalán nem jellemző 1 ....2.....3....4....5.....6....7 Maximálisan jellemzó}

4. Vannak, akik általában nem nagyon boldogok; bár nem depressziósak, soha nem túnnek olyan boldognak, mint amilyen boldogok lehetnének. Milyen mértékben jellemző ez önre?

\section{Egyáltalán nem jellemző 1 .....2....3....4....5....6.....7 Maximálisan jellemzó}

Rating: After inversely rating item 4, add up the scores for the four-items to obtain a total score for SHS-HU; A higher score is an index of greater happiness. 


\title{
A Subjective Happiness Scale magyar változatának (SHS-HU) pszichometriai validálása
}

\author{
SZABÓ ATTILA
}

\begin{abstract}
A Szubjektív Boldogság Skála (Subjective Happiness Scale; SHS) több nyelven is validálásra került, ami népszerúségét és megbízhatóságát sugallja az észlelt boldogság értékelésében. A jelen tanulmányban tárgyalt két vizsgálat célja a magyar nyelvú változat pszichometriai tulajdonságainak a vizsgálata önkéntes felnőttek $(n=252)$ és nem-önkéntes egyetemi hallgatók $(n=142)$ mintáján. Az önkéntesektől gyưjtött adatok feltáró faktoranalízise megerősítette a magyar SHS (SHS-HU) egydimenziós szerkezetét. Egy komponens a variancia 53,69\%-át magyarázta. Az SHS-HU belső megbízhatósága is jó volt (Cronbach-a $=0,80)$. A nem-önkéntes egyetemi hallgatók adatainak megerósítő faktoranalízise kiváló modellilleszkedést eredményezett $(\mathrm{SRMR}=0,0208$; NFI = 0,990; GFI = 0,995; RMSEA < $0,001 ; \mathrm{CFI}=1,00$ ) és elfogadható volt a belső konzisztenciája (Cronbach- $\alpha=0,75)$. Az SHSHU egyhetes ismételt méréses teszt-reteszt korrelációjának az eredménye 0,83 volt. Mindkét tanulmányban a kérdőív pozitív irányú összefüggésben állt az élettel való elégedettséggel és optimizmussal, míg fordítottan korrelált a pesszimizmussal $(p<0,001)$. Mindkét tanulmányban az optimistábbak magasabb boldogság értékeket jelentettek, mint a kevésbé optimisták $(p<0,001)$, amely eredmények megerősítették a skála tartalmi érvényességét. Továbbá, az elégedettség, optimizmus és a pesszimizmus ellenőrzése során nem mutatkozott szignifikáns nemi különbség az SHS-HU-pontszámokban. Ezek az eredmények az SHS-HU megfelelő pszichometriai tulajdonságait sugallják. Következtetésképpen, az SHS-HU ígéretes kérdőív az észlelt boldogság mérésére magyar mintákban is.
\end{abstract}

Kulcsszavak: affektivitás, élettel való elégedettség, jóllét, optimizmus, pesszimizmus

This is an open-access article distributed under the terms of the Creative Commons Attribution 4.0 International License (https://creativecommons.org/licenses/by/4.0/), which permits unrestricted use, distribution, and reproduction in any medium, provided the original author and source are credited, a link to the CC License is provided, and changes - if any - are indicated. (SID_1) 
